\title{
The Brazilian version of the Hip Sports Activity Scale: translation and cross-cultural adaptation
}

\author{
Letícia Nunes Carreras Del Castillo Mathias', Themis Moura Cardinot", Danúbia da Cunha de Sá-Caputo"', Márcia Cristina \\ Moura-Fernandes"v, Mário Bernardo-Filhov", Gustavo Leporace de Oliveira Lomelino Soares ${ }^{\mathrm{VI}}$, Luiz Alberto Batista ${ }^{\mathrm{vII}}$, \\ Liszt Palmeira de OliveiravilI
}

Universidade do Estado do Rio de Janeiro (UERJ), Rio de Janeiro (RJ), Brazil

'MSc. Physiotherapist and Doctoral Student, Programa de Pós-Graduação em Ciências Médicas (PGCM), Universidade do Estado do Rio de Janeiro (UERJ), Rio de Janeiro (RJ), Brazil.

(D) https://orcid.org/0000-0003-2938-2551

"PhD. Physical Educator and Professor, Departamento de Ciências Farmacêuticas (DCFar), Instituto de Ciências Biológicas e da Saúde (ICBS), Universidade Federal Rural do Rio de Janeiro (UFRRJ), Seropédica (RJ), Brazil

(D) https://orcid.org/0000-0003-4191-0468

IIPhD. Physiotherapist and Researcher, Laboratório de Vibrações Mecânicas e Práticas Integrativas (LAVIMPI), Departamento de Biofísica e Biometria, Instituto de Biologia Roberto Alcântara Gomes, Policlínica Piquet Carneiro (PPC), Universidade do Estado do Rio de Janeiro (UERJ), Rio de Janeiro (RJ), Brazil.

(D) https://orcid.org/0000-0002-9263-1576

"MSc. Physiotherapist and Doctoral Student, Laboratório de Vibrações Mecânicas e Práticas Integrativas (LAVIMPI), Departamento de Biofísica e Biometria, Instituto de Biologia Roberto Alcântara Gomes, Policlínica Piquet Carneiro (PPC), Universidade do Estado do Rio de Janeiro (UERJ) Rio de Janeiro (RJ), Brazil.

(D) https://orcid.org/0000-0003-2784-066X

vphD. Physiotherapist and Professor, Laboratório de Vibrações Mecânicas e Práticas Integrativas (LAVIMPI), Departamento de Biofísica e Biometria, Instituto de Biologia Roberto Alcântara Gomes, Policlínica Piquet Carneiro (PPC), Universidade do Estado do Rio de Janeiro (UERJ), Rio de Janeiro (RJ), Brazil. (D) https://orcid.org/0000-0002-4718-448X

"PhD. Physical Educator and Physiotherapist, Departamento de Diagnóstico por Imagem, Escola Paulista de Medicina, Universidade Federal de São Paulo (UNIFESP), São Paulo (SP), Brazil.

(D) https://orcid.org/0000-0002-7265-4658

vilPhD. Physical Educator and Professor, Programa de Pós-Graduação em Ciências Médicas (PGCM), Universidade do Estado do Rio de Janeiro (UERJ) Rio de Janeiro (RJ), Brazil.

(D) https://orcid.org/0000-0002-4609-4095

"IIIMD, PhD. Orthopedist and Professor, Programa de Pós-Graduação em Ciências Médicas (PGCM), Universidade do Estado do Rio de Janeiro (UERJ), Rio de Janeiro (RJ), Brazil.

(D) https://orcid.org/0000-0002-9051-937X

KEYWORDS (MeSH terms):

Surveys and questionnaires.

Femoroacetabular impingement.

Sports.

Translations.

Hip injuries.

Exercise.

AUTHORS' KEYWORDS:

Cultural equivalence.

Cultural adaptation.

Questionnaire.

Physical activity.

\section{ABSTRACT}

BACKGROUND: The Hip Sports Activity Scale (HSAS) is a reliable and valid tool for determining the levels of sports activities among patients with femoroacetabular impingement (FAl).

OBJECTIVE: To translate and cross-culturally adapt the HSAS to the Brazilian Portuguese language.

DESIGN AND SETTING: This was a cross-sectional study conducted at the State University of Rio de Janeiro. METHODS: The Brazilian version of the HSAS was developed following a process that comprised six steps: translation, synthesis, back-translation, review by committee, pretesting and submission of documentation to the developers. The translation phase involved three independent bilingual translators whose mother language was Brazilian Portuguese. The back-translation phase involved three independent translators whose mother language was English. In order to verify comprehension of the questionnaire, 30 undergraduate students in physical education (65\% men), with mean age 23.2 years (standard deviation $=6.8$ ), participated in the pre-testing phase.

RESULTS: During the translation step, some terms and expressions were changed to obtain cultural equivalence to the original HSAS. In the pre-testing phase, each item of the scale showed a comprehension level of $100 \%$.

CONCLUSION: The HSAS was translated from English to the Brazilian Portuguese language and adapted to Brazilian culture. The HSAS validation is ongoing.

\section{INTRODUCTION}

There is growing evidence that femoroacetabular impingement (FAI) plays an important role in the mechanical etiology of the development of hip arthrosis. This abnormal contact between the acetabulum and the femoral neck during hip mobilization, especially during flexion and internal rotation, limits the range of motion. ${ }^{1,4}$ Impact can occur in patients who subject their hip to extreme ranges of motion, which can cause compression of the non-spherical extension of the supraphysiological head. ${ }^{5}$

Individuals with FAI complain mainly of chronic pain, with insidious onset, long duration and progressive worsening. ${ }^{6}$ Physical exercise generally causes exacerbations. In addition to sports activities, activities of daily living can also be associated with pain: for example, climbing stairs, sitting after a prolonged lying session, moving in bed and getting in and out of a car. The typical patient is a young adult, usually practicing sports that involve hip flexion. Pain can be constant, or intermittent at rest, and can interfere with sleep. ${ }^{1-7}$

Sports activities that require vigorous and repetitive flexion and internal hip rotation, such as ice hockey or football, are often associated with symptomatic FAI. In addition to these, martial arts such as kickboxing, taekwondo and kung-fu, and also speed athletics and hurdles, can be mentioned.

In this context, use of instruments to assess various aspects of health among individuals with different clinical conditions, in the form of questionnaires and scales, has proved to be very promising, based on patients' perceptions of their health status. ${ }^{8,9}$

The Hip Sports Activity Scale (HSAS) is a reliable and valid tool for determining the levels of sports activities among patients who suffer femoroacetabular impingement. The original article was published by Naal et al. in 2013. ${ }^{10}$ Their research group has developed and validated a sports activity scale for patients with a diagnosis of femoroacetabular impingement, in English and German. The HSAS is composed of nine different levels of physical activity. It has nine items 
scored from 0 to 8 , such that 0 represents sedentary individuals and 8 represents high-performance athletes, with no subscales. It has been widely used in English-speaking countries.

Many instruments have been developed in the English language. ${ }^{11,12}$ For them to be used in populations with different languages and cultures, it is necessary to follow a set of steps for their translation, cultural adaptation and validation, in order to ensure that the new instrument maintains the characteristics of the original version. ${ }^{13,14}$

\section{OBJECTIVE}

The aim of this study was to translate the HSAS from English to the Brazilian Portuguese language and to cross-culturally adapt it to Brazilian culture. Our hypothesis was that the translation to Brazilian Portuguese and the cultural adaptation for use in Brazil would be feasible and acceptable.

\section{METHODS}

\section{Type of study}

This was a cross-sectional study of quantitative and qualitative nature on the translation and cross-cultural adaptation of a questionnaire, using data obtained between December 2014 and June 2015.

This study was approved by the ethics committee of our institution (number 998.832; date: March 15, 2015) and all subjects signed an informed consent statement. Dr. Florian D. Naal (the first author of the HSAS) gave permission for us to translate and cross-culturally adapt the HSAS to the Brazilian Portuguese language.

\section{Translation and cross-cultural adaptation}

To translate and adapt the HSAS, the guidelines suggested by Guillemin et al. ${ }^{13}$ and reviewed by Beaton et al. ${ }^{14}$ were followed. The process comprised six steps: translation, synthesis, backtranslation, review by committee, pretesting and submission of documentation to the developers (Figure 1).

\section{Translation (into the Brazilian Portuguese language)}

The original English version of the HSAS was translated from English to Brazilian Portuguese by three independent translators (two physiotherapists and one orthopedist) with experience of hip treatment. They were informed about the purpose of the study. Three different Brazilian Portuguese translations were produced: T1, T2 and T3.

\section{Synthesis (of translations produced into the Brazilian Portu- guese language)}

A multidisciplinary committee composed of two physiotherapists, three orthopedists and two physical educators was formed to evaluate these three initial Brazilian Portuguese translations (T1, T2

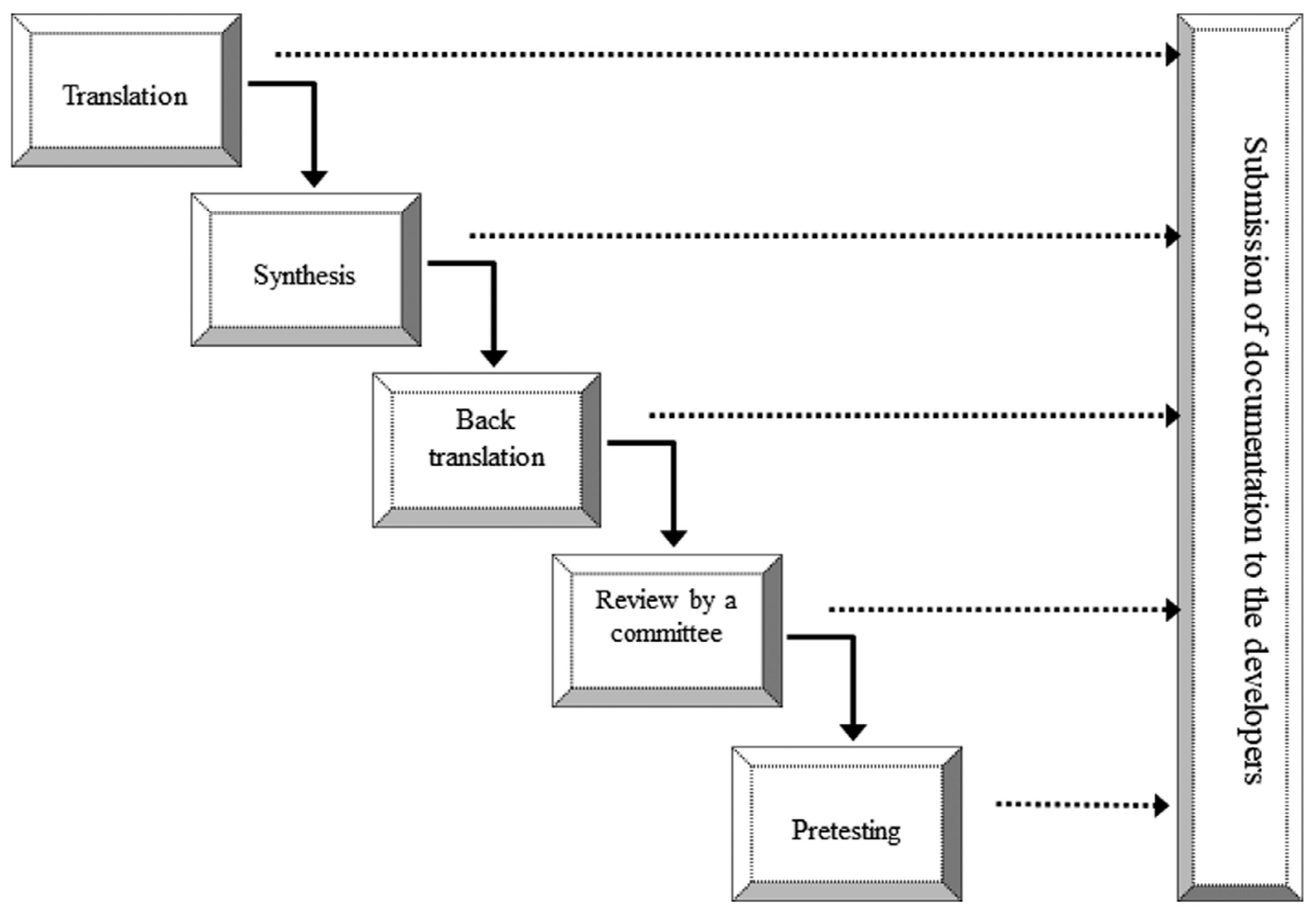

Figure 1. Steps of translation and cross-cultural adaptation according to the guidelines of Guillemin et al. and Beaton et al.: translation, synthesis, back-translation, review by a committee, pretesting and submission of documentation to the developers. ${ }^{13,14}$ 
and T3) that were produced in the translation step. Possible distortions and their applicability were analyzed. A synthesis (S1) of these three Brazilian Portuguese translations was produced.

\section{Back-translation (into the English language)}

This Brazilian Portuguese synthesis (S1) was then back-translated into English by three independent translators who were unaware of the purpose of the translation. Three different backtranslations into English were produced: BT1, BT2 and BT3.

\section{Review by a committee (revised translation into the Brazilian Portuguese language)}

The multidisciplinary committee that had been formed for backtranslation reviewed these three back-translations into English (BT1, BT2 and BT3), in comparison with the original HSAS in English, and a revised translation into the Brazilian Portuguese language (RT) was developed. During this step, this committee verified the semantic, idiomatic, cultural and conceptual equivalences, in order to carry out the process of cultural adaptation for Brazil.

\section{Pretesting (cultural equivalence)}

The objective of this step was to assess situations, issues or terms that were not well understood. Thirty undergraduate students of physical education gave responses to the revised translation (RT) that had been produced in the review by the committee. No instructions to indicate whether there was an unknown term or sport, or to suggest sports that were not present on the scale, were given to the participants. We found that there were no questions with an incomprehension rate of more than $15 \%$, and the students did not consider any of the questions to be not applicable. Based on these results, this revised translation (RT) was considered to be the final translation of HSAS.

\section{Submission of documentation to the developers}

The last step of the adaptation process was to send all the reports and forms to the developers of the translated version of the instrument.

\section{RESULTS}

The sociodemographic characteristics of the 30 participants are shown in Table 1. Sixty-five percent of the volunteers were male, aged between 18 and 45 years, and 100\% had completed high school education.

Table 2 shows the changes made through verifying the semantic, idiomatic, cultural and conceptual equivalences, in order to carry out the cultural adaptation of the HSAS for use in Brazil.

After these changes had been made by the multidisciplinary committee (at the step of review by a committee), the revised translation into Brazilian Portuguese language (RT) was produced.
In the pretesting, thirty volunteers, undergraduate students of physical education, gave responses to the RT. The results showed that there were no questions with an incomprehension rate of more than $15 \%$, and the students did not consider any of the questions to be not applicable. From this result, our assessment was that the RT of the HSAS was well understood. Thus, the RT was considered to be the final translation of the HSAS, i.e. the HSAS-Brazil.

The original HSAS and the HSAS-Brazil adaptations are shown in Box 1. The HSAS-Brazil scale is available for download in Annex 1.

\section{DISCUSSION}

The HSAS was translated into the Brazilian Portuguese language and was cross-culturally adapted into Brazilian culture, thus confirming our hypothesis that adaptation of this scale for use in Brazil was indeed feasible and acceptable.

Guillemin et al. ${ }^{13}$ and Beaton et al. ${ }^{14}$ suggested in their guidelines that at least two translations of the original questionnaire or scale into the target language should be produced. In our study, we chose to perform three translations into Brazilian Portuguese language (T1, T2 and T3) and, consequently, three back-translations into English (BT1, BT2 and BT3) were produced. In the cross-cultural adaptations of the Harris Hip Score (HHS), ${ }^{15}$ the International Knee Documentation Committee (IKDC), ${ }^{16}$ the Nonarthritic Hip Score (NAHS) ${ }^{17}$ and the Hip Outcome Score (HOS ${ }^{18}$ questionnaires, only two translations and two back-translations were performed for each of them. We believe that these three translations

Table 1. Sociodemographic data on the thirty volunteers for pretesting

$\begin{array}{lcc}\text { Volunteers for pretesting } & \text { Female } & 20 \\ \text { Gender } & \text { Male } & 10 \\ \text { Age (years) } & \text { Mean (standard deviation) } & 23.2(6.8) \\ \text { Marital status } & \text { Married } & 2 \\ \text { Education } & \text { Single } & 28 \\ & \text { High school not completed } & 0 \\ & \text { High school completed } & 30\end{array}$

Table 2. Modifications made to the Hip Sports Activity Scale (HSAS) within the cross-cultural adaptation for Brazil

$\begin{array}{lc}\text { Original HSAS } & \text { Modified to } \\ \text { Ice hockey and field hockey } & \text { Hockey } \\ \text { Snowboarding } & \text { Wakeboarding } \\ \text { Skiing } & \text { Surfing } \\ \text { Lacrosse } & \\ \text { Cross-country skiing/Biathlon } & \text { Removed } \\ \text { Cricket } & \\ \text { Racketball } & \\ \text { Badminton } & \end{array}$


Box 1. The original Hip Sports Activity Scale (HSAS) and the Brazilian version (HSAS-Brazil)

\section{Hip Sports Activity Scale (HSAS - English version) \\ Please mark in the following list your current highest level of sports or recreational activity.}

\section{Competitive Sports (elite level)}

Soccer, Ice hockey, Field hockey, American football/Rugby, Martial arts, Tennis, Track-and-field, Indoor sports*, Beach-Volleyball, Lacrosse, Baseball/Softball

\section{Competitive Sports (elite level)}

Downhill skiing, Snowboarding

\section{Competitive Sports (minor leagues/collegiate)}

Soccer, Ice hockey, Field hockey, American football /Rugby, Martial arts, Tennis, Track-and-field, Indoor sports*, Beach-Volleyball, Lacrosse, Baseball/Softball

\section{Competitive Sports (elite level)}

Golf, Bicycle racing, Mountain biking, Swimming, Rowing, Cross-country skiing/Biathlon, Horseback riding, Cricket

Competitive Sports (minor leagues/collegiate)

Downhill skiing, Snowboarding

5. Competitive Sports (minor leagues/collegiate)

Golf, Bicycle racing, Mountain biking, Swimming, Rowing, Cross-country skiing/Biathlon, Horseback riding, Cricket

Recreational Sports

Soccer, Ice hockey, Field hockey, American football/Rugby, Martial arts, Track-and-field, Beach-Volleyball, Lacrosse

\section{Recreational Sports}

Tennis, Downhill skiing, Snowboarding, Indoor sports*, Baseball/Softball

\section{Recreational Sports}

Aerobics, Jogging, Lower extremity weight-training, Horseback riding, Cricket

2. Recreational Sports

Golf, Bicycle racing, Mountain biking, Swimming, Rowing, Cross-country

skiing/Biathlon, Dancing, Inline skating

\section{Recreational Sports}

Swimming, Cycling, Hiking, Nordic walking (quick walking with ski-poles)

\section{No Recreational or Competitive Sports}

*Indoor Sports: Basketball, Squash, Racketball, Handball, Badminton, Volleyball Please indicate your preferred sport:
Escala de Atividade Esportiva do Quadril (HSAS-Brasil)

Por favor, marque na lista a seguir o mais alto nível de atividade esportiva ou recreacional atual que você consegue realizar.

8. Esportes de Competição (nível elite)

Futebol, Hóquei, Futebol americano/Rugby, Artes marciais, Tênis, Atletismo, Esportes de quadra*, Vôlei de praia, Beisebol/Softbol

\section{Esportes de Competição (nível elite)}

Surfe, Wakeboard

Esportes de Competição (ligas menores/estudantil)

Futebol, Hóquei, Futebol americano/Rugby, Artes marciais, Tênis, Atletismo, Esportes de quadra*, Vôlei de praia, Beisebol/Softbol

\section{Esportes de Competição (nível elite)}

Golfe, Ciclismo, Mountain bike, Natação, Remo, Hipismo

Esportes de Competição (ligas menores/estudantil)

Surfe, Wakeboard

5. Esportes de Competição (ligas menores/estudantil)

Golfe, Ciclismo, Mountain bike, Natação, Remo,

Hipismo

Esportes Recreativos

Futebol, Hóquei, Futebol americano/Rugby, Artes marciais, Tênis, Atletismo, Vôlei de praia

\section{Esportes Recreativos}

Tênis, Surfe, Wakeboard, Esportes de quadra*,

Beisebol/Softbol

\section{Esportes Recreativos}

Ginástica aeróbica, Corrida, Musculação para membros inferiores, Hipismo

2. Esportes Recreativos

Golfe, Ciclismo, Mountain bike, Natação, Remo,

Dança, Patinação

\section{Esportes Recreativos}

Natação, Andar de bicicleta, Caminhada em trilhas, Caminhada em alta velocidade.

0. Nenhum Esporte Recreativo ou de Competição

*Esportes de Quadra: Basquete, Squash, Handebol, Vôlei

Por favor, indique seu esporte preferido: and three back-translations carried out by our group helped to produce a more careful and refined version of the HSAS-Brazil.

Questionnaires and scales developed in a foreign language need a careful cross-cultural adaptation process in order to allow them to be used in another sociocultural reality. ${ }^{13}$ The aim of the cross-cultural adaptation is to ensure consistency in content validity between the versions of the questionnaire (original language and target language). Subtle differences in life habits between different cultures can make an item on a questionnaire or scale more or less difficult to understand, thus changing the psychometric and statistical properties of the instrument. ${ }^{14}$ In our study, we decided to change the structure of the original instrument as little as possible: the changes made were extremely necessary for the process of adapting the HSAS to Brazilian culture.

"Ice hockey" and "field hockey" were considered to be "hockey" without discrimination between ice hockey and field hockey, since Brazilians do not usually practice ice hockey. As Brazilians are not used to "Nordic walking", it was switched to "walking at high speed". "Downhill skiing" and "snowboarding" were replaced by "surfing" and "wakeboarding", water sports that are relatively 
popular in Brazil and because the skiing body movement is similar to that performed in surfing. In the cultural adaptation of the IKDC questionnaire, Metsavaht et al. ${ }^{16}$ also changed "skiing" to "surfing" because of the popularity of this sport in Brazil and the similarity of the stress applied to the knees while practicing these two sports activities.

"Cross-country skiing" and "cricket" were suppressed as they are not practiced in Brazil and because it was not possible to find an equivalent sport for them. "Biathlon" was also suppressed because it is included in cycling and swimming. "Badminton" was suppressed because it is not popular in Brazil; and, lastly, "racketball" was also suppressed because Brazilians seem to consider that this is the same as "squash".

These changes were approved by the main author of the HSAS and these adaptations for the Brazilian version (HSAS-Brazil) are shown in Box 1.

In the pretesting, thirty volunteers who were undergraduate students of physical education gave responses to the revised HSAS translation into Portuguese (RT), so that we could assess comprehension of the scale and the semantic, idiomatic, cultural and conceptual equivalences. It was observed that other cultural adaptation studies also applied pretesting to a similar number of patients. Oliveira et al. ${ }^{18}$ applied pretesting of the HOS questionnaire to 30 patients with hip pain without arthrosis. Guimarães et al. ${ }^{15}$ administered pretesting of the HHS questionnaire to 30 patients with hip disorders. Del Castillo et al. ${ }^{17}$ performed pretesting of the NAHS questionnaire among 10 patients with hip pain and 20 healthy adults without hip pain.

One limitation of this study may have been the fact that the group of individuals who underwent the pretesting did not correspond to the target population of the scale, i.e. patients suffering from femoroacetabular impingement. However, for most questionnaires, the translations were not culturally adapted among individuals in their target population. ${ }^{13}$ Another limitation may have been the fact that the pretesting group was formed by undergraduate students, which does not reflect the general level of education of the Brazilian population. According to the Brazilian Institute for Geography and Statistics (Instituto Brasileiro de Geografia e Estatística, IBGE), half of all Brazilians have only attended school up to completion of elementary school. ${ }^{19}$

The strength of this study was its use of this tool to determine the levels of physical and sports activity, which is essential for evaluating younger patients, who tend to be physically very active. Their level of physical activity and participation in sports activities is an important prognostic factor. In addition, the pre-existing level may be directly related to the expectations desired by the patient. In this way, the HSAS contributes to filling the gap that existed among the questionnaires and scales for assessing the physically active population that suffers from femoroacetabular impingement.

\section{CONCLUSION}

The Hip Sports Activity Scale was translated into the Brazilian Portuguese language and adapted to Brazilian culture. Our hypothesis that use of this scale in the Brazilian Portuguese language and Brazilian culture would be feasible and acceptable was found to be true. The validation process on the Hip Sports Activity Scale in Brazil is ongoing.

\section{REFERENCES}

1. Volpon JB. Femoroacetabular impingement. Rev Bras Ortop. 2016;51(6):621-29. PMID: 28050531; https://doi.org/10.1016/j. rboe.2016.10.006.

2. Crestani, MV, Teloken, MA, Gusmão PDF. Impacto femoroacetabular: uma das condições precursoras da osteoartrose do quadril. Rev Bras Ortop. 2006;41(8):285-93. https://doi.org/10.1016/j.rboe.2016.10.006.

3. Beck M, Kalhor M, Leunig M, Ganz R. Hip morphology influences the pattern of damage to the acetabular cartilage: femoroacetabular impingement as a cause of early osteoarthritis of the hip. J Bone Joint Surg Br. 2005;87(7):1012-8. PMID: 15972923; https://doi. org/10.1302/0301-620X.87B7.15203.

4. Tannast M, Siebenrock KA, Anderson SE. Femoroacetabular impingement: radiographic diagnosis - what the radiologist should know. AJR Am J Roentgenol. 2007;188(6):1540-52. PMID: 17515374; https://doi.org/10.2214/AJR.06.0921.

5. Farkas GJ, Cvetanovich GL, Rajan KB, et al. Impact of Femoroacetabular impingement morphology on gait assessment in symptomatic patients. Sports Health. 2015;7(5):429-36. PMID: 26502419; https:// doi.org/10.1177/1941738115592827.

6. Diaz-Lopez RA, Alonso-Rasgado MT, Jimenez-Cruz D, Bailey CG, Board TN. Impact of femoroacetabular impingement and dysplasia of the hip on hip joint sphericity. Hip Int. 2020;30(2):195-203. PMID: 30963778; https://doi.org/10.1177/1120700019834295.

7. Menge TJ, Truex NW. Femoroacetabular impingement: a common cause of hip pain. The Phys Sports Med. 2018;46(2):139-44. PMID: 29406812; https://doi.org/10.1080/00913847.2018.1436844

8. Siqueira Rola CV, Silva SPC, Nicola PA. Instrumentos de avaliação da qualidade de vida de pessoas jovens e idosas: um estudo de revisão sistemática. Rev Mult Psic. 2018;12(42):111-20. Available from: https://idonline.emnuvens. com.br/id/article/view/1300/0. Accessed in 2021 (Jul 16).

9. Del Castillo LN, Leporace G, Cardinot TM, Levy RA, Oliveira LP. A importância dos questionários para avaliação da qualidade de vida. Rev Hosp Univ Pedro Ernesto. 2012;11(1):12-7. Available from: https:// www.e-publicacoes.uerj.br/index.php/revistahupe/article/view/8896. Accessed in 2021 (Jul 16)

10. Naal FD, Miozzari HH, Kelly BT, et al. The Hip Sports Activity Scale (HSAS) for patients with femoroacetabular impingement. Hip Int. 2013;23(2):20411. PMID: 23543465; https://doi.org/10.5301/hipint.5000006.

11. Reis-Junior JR, Protázio JB, Muribeca-de-Casto AM, et al. Brazilian version of the Self-Estimated Functional Inability because of Pain questionnaire 
for musculoskeletal injuries relating to dance and sport: translation and cross-cultural adaptation. São Paulo Med J. 2020;138(10):11-8. PMID: 32321100; https://doi.org/10.1590/1516-3180.2019.0375.r1.08102019.

12. Costa RMP, Cardinot TM, Mathias LNCDC, Leporace G, de Oliveira LP. Validation of the Brazilian version of the Hip Outcome Score (HOS) questionnaire. Adv Rheumatic. 2018;58(1):4. PMID: 30657066; https:// doi.org/10.1186/s42358-018-0007-y.

13. Guillemin F, Bombardier C, Beaton D. Cross-cultural adaptation of health-related quality of life measures: literature review and proposed guidelines. J Clin Epidemiol. 1993;46(12):1417-32. PMID: 8263569; https://doi.org/10.1016/0895-4356(93)90142-n.

14. Beaton DE, Bombardier C, Guillemin F, Ferraz MB. Guideline for the process of cross-cultural adaptation of self-report measures. Spine (Phila Pa 1976). 2000;25(24):3186-91. PMID: 11124735; https://doi. org/10.1097/00007632-200012150-00014.

15. Guimarães RP, Alves DPL, Silva GB, et al. Tradução e adaptação transcultural do instrumento de avaliação do quadril"Harris Hip Score". Acta Ortop Bras. 2010;18(3):142-7. https://doi.org/10.1590/S141378522012000200006

16. Metsavaht L, Leporace G, Ribeiro M, Sposito MM, Batista LA. Translation and cross-cultural adaptation of the Brazilian version of the International Knee Documentation Committee Subjective Knee Form: validity and reproducibility. Am J Sports Med. 2010;38(9):1894-9. PMID: 20472755; https://doi.org/10.1177/0363546510365314.

17. Del Castillo LNC, Leporace G, Cardinot TM, Levy RA, Oliveira LP. Translation, cross-cultural adaptation and validation of the Brazilian version of the Nonarthritic Hip Score. São Paulo Med J. 2013;131(4):24451. MID:24141295; https://doi.org/10.1590/1516-3180.2013.1314487.

18. de Oliveira LP, Moura Cardinot T, Nunes Carreras Del Castillo L, Cavalheiro Queiroz M, Cavalli Polesello G. Translation and cultural adaptation of the Hip Outcome Score to the Portuguese language. Rev Bras Ortop. 2014;49(3):297304. PMID: 26229816; https://doi.org/10.1016/j.rboe.2014.03.011.

19. PNAD Contínua - 2019 Educação. Pesquisa Nacional por Amostra de Domicílios Contínua - Divulgação anual. Instituto Brasileiro de Geografia e Estatística (IBGE); 2020. Available from: https://www. ibge.gov.br/estatisticas/sociais/populacao/17270-pnad-continua. html?edicao=28203\&t=sobre. Accessed in 2021 (Jul 16).

Authors' contributions: Mathias LNCDC: conceptualization (equal), data curation (equal), formal analysis (equal), methodology (equal) and writing-original draft (equal); Cardinot TM: formal analysis (equal), methodology (equal), supervision (equal), writing-original draft (equal) and writing-review and editing (equal); Sá-Caputo DC: formal analysis (equal), methodology (equal), writing-original draft (equal) and writingreview and editing (equal); Moura-Fernandes MC: data curation (equal), formal analysis (equal), methodology (equal) and writing-original draft (equal); Bernardo-Filho M: conceptualization (equal), formal analysis (equal), methodology (equal) and writing-review and editing (equal); Soares GLOL: data curation (equal), formal analysis (equal), methodology (equal) and writing-original draft (equal); Batista LA: conceptualization (equal), formal analysis (equal), methodology (equal) and writingreview and editing (equal); and Oliveira LP: conceptualization (equal), methodology (equal), project administration (equal) and writing-review and editing (equal). All authors approved the final version for publication Acknowledgements: The authors would like to thank Juliana Pessanha de Freitas, Rafaela Maria de Paula Costa, Nathalia Sundin Palmeira de Oliveira and Sarah Silva Sabino for data curation

\section{Sources of funding: None \\ Conflict of interest: None}

Date of first submission: February 28, 2021

Last received: July 19, 2021

Accepted: July 23, 2021

\section{Address for correspondence:}

Letícia Nunes Carreras Del Castillo Mathias

Departamento de Ortopedia e Traumatologia, Hospital Universitário Pedro Ernesto (HUPE), Universidade do Estado do Rio de Janeiro (UERJ)

Boulevard 28 de Setembro, 77

Vila Isabel — Rio de Janeiro (RJ) — Brasil

CEP 20551-030

Tel. (+55 21) 2868-8054

E-mail: leticia.castillo@terra.com.br 
Annex 1. The Brazilian version of the Hip Sports Activity Scale, HSAS-Brasil (Escala de Atividade Esportiva do Quadril).

ESCALA DE ATIVIDADE ESPORTIVA DO QUADRIL (HSAS-BRASIL)

Por favor, marque na lista a seguir o mais alto nível de atividade esportiva ou recreacional atual que você consegue realizar.

8. Esportes de Competição (nível elite)

Futebol, Hóquei, Futebol americano/Rugby, Artes marciais, Tênis, Atletismo, Esportes de quadra*, Vôlei de praia, Beisebol/Softbol.

7. Esportes de Competição (nível elite)

Surfe, Wakeboard.

Esportes de Competição (ligas menores/estudantil)

Futebol, Hóquei, Futebol americano/Rugby, Artes marciais, Tênis, Atletismo, Esportes de quadra*, Vôlei de praia, Beisebol/Softbol.

6. Esportes de Competição (nível elite)

Golfe, Ciclismo, Mountain bike, Natação, Remo, Hipismo.

Esportes de Competição (ligas menores/estudantil)

Surfe, Wakeboard.

5. Esportes de Competição (ligas menores/estudantil)

Golfe, Ciclismo, Mountain bike, Natação, Remo, Hipismo.

Esportes Recreativos

Futebol, Hóquei, Futebol americano/Rugby, Artes marciais, Tênis, Atletismo, Vôlei de praia.

4. Esportes Recreativos

Tênis, Surfe, Wakeboard, Esportes de quadra*, Beisebol/Softbol.

3. Esportes Recreativos

Ginástica aeróbica, Corrida, Musculação para membros inferiores, Hipismo.

2. Esportes Recreativos

Golfe, Ciclismo, Mountain bike, Natação, Remo, Dança, Patinação.

1. Esportes Recreativos

Natação, Andar de bicicleta, Caminhada em trilhas, Caminhada em alta velocidade.

0. Nenhum Esporte Recreativo ou de Competição

*Esportes de Quadra: Basquete, Squash, Handebol, Vôlei.

Por favor, indique seu esporte preferido: 